\title{
STRATEGI SATUAN TUGAS COVID-I 9 KOTA PALANGKA RAYA DALAM PENERAPAN DISIPLIN DAN PENEGAKAN HUKUM PROTOKOL KESEHATAN
}

\author{
PALANGKA RAYA CITY COVID-19 TASK UNIT STRATEGY IN IMPLEMENTATION OF \\ DISCIPLINE AND LAW ENFORCEMENT OF HEALTH PROTOCOL
}

\section{Putri Irianti Sintaman \\ Muhammad Ghopur}

Universitas Muhammadiyah Palangkaraya, Palangka Raya,

Central Kalimantan, Indonesia

Email :

putriiriantisintaman@gmail.com

\begin{abstract}
Abstrak
Penelitian ini bertujuan untuk mengetahui bagaimana Strategi Satuan Tugas Covid-19 Kota Palangkara Raya Dalam Menerapkan Disiplin dan Penegakan Hukum Protokol Kesehatan. Metode yang digunakan dalam penelitian adalah metode kualitatif dimana peneliti bertanya secara langsung dengan informan. Sumber data dalam penelitian ini dari data primer dan data sekunder. Teknik pengumpulan data dalam penelitian ini yaitu: observasi, wawancara dan dokumentasi. Penelitian ini menggunakan pendekatan kualitatif. Teknik pengumpulan data yang digunakan yaitu: I) observasi, 2) wawancara, dan 3) dokumentasi. Berdasarkan hasil dari penelitian mengenai Strategi Satuan Tugas Covid-19 Kota Palangka Raya Dalam Penerapan Disiplin dan Penegakan Hukum Protokol Kesehatan, masih belum maksimal karena faktor yang menghambat keberhasilan pelaksanaan peraturan penerapan disiplin dan penegakan hukum protokol kesehatan antara lain yaitu: Tidak memperdulikan covid-19 sehingga terjadi gesekan antara petugas pelaksanaan peraturan dan masyarakat. $\mathrm{Hal}$ ini dapat dilihat dari aspek ketepat sasaran, tujuan, program, dan kebijakan.
\end{abstract}

Kata Kunci:

Satuan Tugas Covid-19

Penerapan Disiplin dan

Penegakan Hukum Protokol

Kesehatan

\section{Keywords:}

Covid-19 Task Force,

Implementation of Discipline and Enforcement of Health Protocol Law

\begin{abstract}
This study aims to find out how the Palangkara Raya City Covid-19 Task Force Strategy in Implementing Health Protocol Discipline and Law Enforcement. The method used in this research is a qualitative method where the researcher asks questions directly with the informants. Sources of data in this study from primary data and secondary data. Data collection techniques in this study are: observation, interviews and documentation. This study uses a qualitative approach. The data collection techniques used are: I) observation, 2) interviews, and 3) documentation. Based on the results of research on the Strategy of the Covid-1 9 Task Force of the City of Palangka Raya in the Application of Discipline and Law Enforcement of Health Protocols, it is still not optimal due to factors that hinder the successful implementation of regulations for implementing discipline and law enforcement of health protocols, including: There is friction between law enforcement officers and the community. This can be seen from the aspect of targeting, objectives, programs, and policies.
\end{abstract}

(C) 202IThe Authors. Published by Institute for Research and Community Services Universitas Muhammadiyah Palangkaraya. This is Open Access article under the CC-BY-SA License (http://creativecommons.org/licenses/by-sa/4.0/).

\section{PENDAHULUAN}

Pada 2 Maret 2020, untuk pertama kalinya pemerintah mengumumkan dua kasus pasien positif Covid-19 di Indonesia, Pemerintah Indonesia merasa sudah cukup melakukan langkah-langkah antisipasi. Antara lain menggunakan Health Alert Card atau Yellow Card, juga Thermal Scanner untuk mengecek suhu tubuh diatas 38,5 derajat Celsius di pintu masuk dan keluar RI.

Sebagaimana kita ketahui bahwa masuknya virus corona atau covid I 9 di Kalimantan tenggah sejak diumumkannya jumlah total kasus covit 9 di Kalimantan tenggah ada 29 orang dengan progres yakni hasil negatif 10 orang, hasil positif ada 2 orang, dan masih menunggu hasil laboratorium 17 orang. pada hari itu juga provinsi Kalimantan tenggah merubah setatus dari siaga menjadi setatus tanggap darurat. Pada tanggal 20 maret 2020.

Adapun dari semenjak tersebut tingkat penyebaran covid I9 khususnya di kota palangka raya semakin hari semakin meningkat cukup siknifikan, maka dari itu pemerintah kota palangka raya sempat mengambil sikap, sigap dalam mengurangi percepatan pennyebaran covid 9 di kota palangka Raya, dengan memberlakukan pembatasan sosial berskala besar (PSBB). Selama PSBB diberlakukan, jam ke luar rumah warga serta kendaraan yang melintas dilakukan pembatasan. Masyarakat keluar rumah dibatasi hanya sampai pukul 2I.00 WIB, sedangkan moda transportasi hanya diperbolehkan sampai pukul 20.00 WIB hingga kembali normal sampai pukul 06.00 WIB transportasi 
bisa normal kembali.

Namun pada saat ini Pembatasan Sosial Bersekala Besar (PSBB) di kota palangkaraya tidak di berlakukan lagi, namun Wali kota palangka raya mengeluarkan kebijakan melalui Peraturan WALI KOTA PALANGKA RAYA NOMOR 26 TAHUN 2020, TENTANG PENERAPAN DISIPLIN DAN PENEGAKAN PROTOKOL KESEHATAN. Tak hanya sampai disitu pemerintah Kota Palangka Raya mengharapkan dalam di terbitkannya PERWALI tersebut dapat membantu dalam rangka percepatan penanganan corona virus disease 2019 dan pemulihan ekonomi di kota palangka raya.

Setelah di berlakukannya PERWALI tersebut dimulai pada tanggal I4 September 2020 dan diiringi dengan dibentuknya Satuan Tugas Covid-19 Kota Palangka Raya, yang diberikan kewajiban penuh dalam mencegah dan mengendalikankan percepatan penyebaran Covid-19 di kota Palangka Raya, tentunya Satuan Tugas Covid-19 sudah memiliki strategi terhadap pelanggar protokol kesehata dan kerumunan, yang sering terjadi maupun itu perorangan, pelaku usaha, pertemuan yang dilaksanakan masyarakat dengan cara tatap muka secara langsung dan yang sering terjadi di acara pesta pernikahan yang banyak mengundang kerumunan,

Melihat dari tingkat kesadaran masyarakat kota palangka raya masih sebagian besar kita lihat kurangnya kesadaran masyarakat, dalam rangka percepatan penanganan corona virus disease 2019 dan pemulihan ekonomi di kota palangka raya, masyarak masih banyak melanggar peraturan tersebut dengan tidak menggunakan masker saat beraktivitas diluar,tidak mencuci tangan, tidak menjaga jarak dan menghindari kerumunan.

Tentu ini menjadi tugas yang sulit Satuan Tugas Covid-19 Kota Palangka Raya dalam menangani hal tersebut, namun sebagaimana kita ketahui Satgas Covid- 19 terus berusaha keras dalam penanganan hal tersebut dan tentunya memberikan pemahamanpemahaman terkait betapa berbahayanya virus Covid19 ini, Satgas Covid-19 berusaha menenangkan agar masyarakat tidak panik dalam menghadapi musih pandemi saat ini.

$\mathrm{Di}$ dalam hal penerapan disiplin dan penegakan hukum protokol kesehatan jelas untuk mempertegas masyarakat untuk mematuhi peraturan yang dibuat masa pendemi dan memberikan efek jera terhadap pelanggar tidak lain tidak bukan untuk menghentikan penyebaran virus corona di kota palangka raya agar kita semua dapat melakukan kegiatan dengan normal sebagaimana mestinya dan aktivitas perekonomian dapat berjalan dengan baik, lancer tanpa sedikit gangguan apa pun, maka dari itu Satgas Covid- 19 kota palangka Raya mengambil langkah tegas dalam menangani hal tersebut.

Peneliti akan berfokus pada Satuan Tugas Penanganan COVID-19 Kota Palangka Raya sesuai dengan kewenangannya melakukan sosialisasi terkait informasi/edukasi cara pencegahan dan pengendalian
COVID-19, yang di tunjuk untuk melaksanakan Peraturan Wali Kota Palangka Raya Nomor 26 Tahun 2020 Tentang Penerapan Disiplin Dan Penegakan Hukum Protokol Kesehatan. dikarenakan ingin mengetahui bagaimana strategi Satuan Tugas Covid- 19 kota Palangka Raya tersebut selama ini, strategi apa sajakah yang sudah di jalankan oleh Satgas Covid-19 tersebut dalam menangani percepata penyebaran Covid-I 9 di kota Palangka Raya.

\section{TINJAUAN PUSTAKA}

Kata strategi berasal dari bahasa Yunani "strategos" yang artinya suatau usaha yang mencapai kemenangan dalam suatu peperangan awalnya digunakan dalam lingkup militer namun istilah strategi dalam berbagai bidang yang memiliki esens yang relative sama. Strategi iyalah salahsatu alat untuk mencapai suatu tujuan, yang sudah diterapkan oleh suatu organisasi atau instansi agar dapat berjalan untuk mencapai sasaran atau suatu tujuan, baik itu jangka pendek maupun jangka panjang, Setiap orang memiliki definisi berbeda-beda mengenai strategi.

Menurut James Brian Quinn (Mintzberg, Lampel, Quinn, Ghoshal 2003:7), analisis strategi militer diplomatik dan analogo-analogi yang serupa dalam bidang lain menyediakan beberapa wawasan penting kedalam dimensi dasar, sifat dan desain strategi formal.

Pertama, Strategi efektif mengandung tiga unsur penting:

I) Tujuan

Tujuan merupakan hasil yang ingin dicapai oleh suatu organisasi/instansi. Tujuan merupakan salah satu dimensi yang dapat menciptakan sebuah strategi karena penetapan tujuan sangat berkaitan langsung dengan strategi yang akan digunakan oleh sebuah organisasi atau instansi dalam pencapaian tujuannya dimana ketika tujuan sudah di tetapkan maka kita dapat mengetahui strategi yang akan digunakan.

2) Kebijakan

Kebijakan merupakan rangkaian keputusan yang membimbing dan memebatasi tindakan yang dilakukan. Kebijakan dibuat untuk menetapkan arahan suatu tujuan yang ditetapkan sehingga pembuatan kebijakan lebih memudahkan untuk mengarahkan suatu organisasi atau instansi dalam menerapkan suatu strategi.

3) Program

Program merupakan urutan-urutan tindakan yang dilakukan dalam mencapai tujuan yang ditetapkan. Program dimaksudkan untuk mengatur segala tindakantindakan yang akan dilakukan sehingga strategi yang akan diterapkan dapat terlaksana dengan maksimal.

Oleh karna itu strategi sangatlah dibutuhkan dalam sebuah organisasi atau instansi untuk rencana-rencana jangka panjang ataupun jangka pendek dengan diikuti sebuah tindakan-tindakan yang diperuntukan untuk mencapai tujuan tertentu yang umumnya adalah keberhasilan, Strategi disusun dan implementasikan untuk mencapai berbagai tujuan yang telah ditetapkan, Sakaligus untuk mempertahankan dan memperluas 
aktivitas organisasi atau instansi dalam bidang-bidang baru dalam rangka merespon lingkungan.

\section{METODE PENELITIAN}

Berdasarkan permasalahan yang diangkat penulis, maka penelitian ini menggunakan metode penelitian deskriptif kualitatif. Jenis penelitian ini menggunakan pendekatan kualitatif, menurut Kirk \& Muller (Anggito 2018: 7-8) mendefinisikan bahwa penelitian kualitatif adalah tradisi tertentu dalam ilmu pengetahuan sosial yang secara fundamental bergantung dari pengamatan pada manusia baik dalam kawasannya maupun dalam peristilahannya.

Waktu penelitian ini dilakukan pada bulan april hingga bulan juli 2021. Lokasi penelitian adalah dimana penelitian dilakukan, yang mana peneliti menemukan keadaan yang sebenarnya dari objek yang diteliti untuk mendapatkan data yang valid, akurat dan merupakan keperluan dalam penelitian. Dalam hal ini, lokasi penelitian terletak di lingkungan masyarakat, Satuan Tugas Covid-19 Kota Palangka Raya.

\section{HASIL DAN PEMBAHASAN}

Berdasarkan hasil penelitian tentang Strategi Satuan Tugas Covid-19 Kota Palangka Raya Dalam Penerapan Disiplin Dan Penegakan Hukum Protokol Kesehatan maka dapat dijelaskan sebagai berikut: I. Tujuan

Tujuan merupakan salah satu usaha Satuan Tugas Covid-19 dalam mencapai suatu rencana atau mencapai strategi-strategi yang telah disusun, untuk menghadapi masa pendemi pada saat sekarang ini agar masyarakat tidak lagi khawatir dan panik dengan kondisi yang mencekam, agar masyarakat dapat menjalankan aktivitas seperti bekerja, ibadah dan melengsukan acara perkumpulan yang mengharus dilaksana dengan tatapmuka secara langsung, maupun hal-hal yang lainnya.

Kurangnya pemberian informasi mengenai Strategi Satuan Tugas Covid-19 Kota Palangka Raya Dalam Penerapan Disiplin Dan Penegakan Hukum Protokol Kesehatan, Kepada masyarakat maka akan menjadi penghambat terhadap keberhasilan suatu apapun dan tidak menutup kemungkinan akan terjadinya pelanggaran-pelanggaran dikemudian harinya.

Dari wawancara yang telah dilakukan dengan berbagai narasumber yang relevan maka didapatkan hasil peneliti bahwa : Pada dasarnya tujuan dibentuknya satuan tugas covid-19 untuk membantu pemerintah kota Palangka Raya dalam mencegah dan mengendalikan covid-19 dilingkungan masyarakat, agar dapat terkendali dan dalam kondisi pandemi seperti sekarang masyarakat tidak tertekan. Satuan tugas covid-1 9 berkomitmen dalam melaksanakan tugas yang telah diamanahk an oleh pemerintah pusat khususnya pemerintah kota Palangka Raya.

Selanjutnya, masyarakat sudah mengetahui tujuan dibentuknya Satuan Tugas Covid-19 Kota Palangka Raya, Tujuan pendisiplinan dan penegakan hukum protokol kesehatan. Masyarakat sangat mendukung hal tersebut karena merupakan langkah yang tepat dan nyata dalam mencegah penularan Covid-19 dilingkungan Kota Palangka Raya. Masyarakat diharapkan dapat menerapkan hal tersebut untuk kepentingan bersama agar Covid-19 dapat dicegah secara bersama-sama, karena dengan kekompakan masyarakat dan petugas, pandemi dapat dilewati secara bahu membahu sehingga dapat kembali normal seperti dahulu.

2. Kebijakan

Satuan tugas Covid-19 Kota Palangka Raya selaku instansi yang diberikan tanggung jawab penuh oleh pemerintah kota dalam rangka melaksanakan Peraturan Wali Kota Palangka Raya Nomor 26 Tahun 2020 Tentang Penerapan Disiplin Dan Penegakan Hukum Protokol Kesehatan tersebut dalam penerapan pelaksanaan, pengawasan dan penegakan hukum terhadap masyarakat yang melanggar kebijakan yang telah dikeluarkan oleh pemerintah kota Palangka Raya, diharapkan dapat melaksanakan atau menerapkan peraturan Wali Kota tersebut semua pihak yang terkait didalamnya.

Masyarakat dan lain sebagainya merupakan pihak yang diwajibkan mematuhi peraturan tersebut dan melaksanakan kewajibannya yaitu dengan melakukan tidak keluar rumah jika dirasa tidak penting, menghindari perkumpulan atau kerumunan yang terpenting menggunakan masker, mencuci tangan, menjaga kesehatan fisik atau tubuh agar selalu sehat terhindar dari penyakit, sehingga pelaksanaan isi kebijakan yang Diterapkan Satuan Tugas Covid-19 Kota Palangka Raya dalam Penerapan disiplin Dan Penegakan Hukum Protokol Kesehatan dapat terealisasi dengan baik, sehingga dapat mengendalikan dan mencegah penyebaran Covid-19.

Dari wawancara yang telah dilakukan dengan berbagai narasumber yang relevan maka didapatkan hasil peneliti bahwa :

Berdasarkan hasil wawancara bahwa pemkot Palangkaraya juga membuat sebuah kebijakan hukum, yang tercantum dalam peraturan wali kota Palangka Raya nomor 26 tahun 2020. Pasal 3 Subjek pengaturan Peraturan Walikota ini meliputi : a. perorangan (melakukan 4M : memakai masker, mencuci tangan, menjaga jarak dan menghindari kerumunan); b. pelaku usaha (menyiapkan sarana dan parasarana $4 \mathrm{M}$ bagi karyawan dan pengunjung yang datang); dan c. pengelola, penyelenggra, atau penanggung jawab tempat dan fasilitas umum (menyiapkan sarana dan prasarana $4 \mathrm{M}$ bagi karyawan dan pengunjung yang datang).

Selanjutnya, Masyarakat sangat mendukung dan meapresiasi kebijakan yang telah dijalankan oleh Satuan Tugas Covid-19, karena masyarakat menginginkan agar kebijakan ini dapat diimpelemtasikan dengan setegastegasnya. Sehingga tidak adalagi masyarakat yang yang melanggar ketentuan yang telah dijalankan. Masyarakat diminta agar lebih dewasa dalam menjalankan kebijakan, masyarakat harus disiplin dalam menerapkan 
protokol kesehatan dan menerima sanksi penegakan hukum protokol kesehatan agar tidak terjadi gesekan antara petugas penegak hukum protokol kesehatan.

\section{Program}

Program merupakan usaha Satuan Tugas Covid19 Kota Palangka Raya dalam menindak lanjuti penerapan disiplin dan penegakan hukum protokol kesehatan pada masa pandemi ini, agar kegiatan dapat berjalan normal atau disebut dengan New Normal, adapun strategi sangat dibutuhkan untuk menjalankan program yang sudah disusun oleh Satgas Covid-19 dan dapat memperlancar program-program yang hendak di capai.

Dari wawancara yang telah dilakukan dengan berbagai narasumber yang relevan maka didapatkan hasil peneliti bahwa :

Berdasarkan hasil wawancara bahwa satgas kota palangka raya telah melakukan program untuk pencegahan penyebaran Covid 19 dengan melakukan pengawasan terhadap masyarakat dalam artian setiap kegiatan masyarakat yang berpotensi menimbulkan kerumunan, seperti kegiatan melangsungkan pernikahan, kegiatan seminar dan satgas Covid- 19 juga telah melakukan program penyemprotan disinfektan keperumahan warga, tempat-tempat fasilitas umum satu minggu sekali. Selanjutnya, Mengenai program, masyarakat menyambut dengan baik dengan adanya program yang dijalankan oleh tim Satuan Tugas Covid-19 Kota Palangka Raya. Program tersebut merupakan harapan masyarakat dan diharapkan dapat berjalan dengan baik dan lancar, namun adapula masyarakat menghawatirkan pembatasan kegiatan yang dapat memberikan dampak terhadap pekerjaan secara langsung maupun tidak langsung sehingga dapat menguragi pendapatan. Masyarakat tidak perlu khawatir karena Satuan Tugas Covid-19 hanya memberikan solusi melalui program agar kegiatan dapat berjalan namun tetap memperhatikan protokol kesehatan.

\section{KESIMPULAN}

Dari hasil pengamatan dan pembahasan penelitian ini, maka penulis dapat menyimpulkan bahwa:

Satuan tugas covid-19 kota Palangka Raya merupakan instansi yang dibetuk untuk menerapkan peraturan pemerintah khususnya pemerintak kota Palangka Raya dalam penerapan disiplin dan penegakan hukum protokol kesehatan dilingkungan kota Palangka Raya.

Dalam pelaksanaannya satuan tugas covid- 19 kota Palangka Raya telah menyampaikan informasi tujuan, kebijakan dan program mengenai penerapan disiplin dan penegakan hukum protokol kesehatan kepada masyarakat dikota Palangka Raya dalam betuk sosialisasi, patrol dan penindakan ditempat.

Untuk menunjang keberhasilan pelaksanaan peraturan penerapan disiplin dan penegakan hukum protokol kesehatan oleh satuan tugas covid-19 kota Palangka Raya berkoordinasi atau bekerja sama dengan instansi pemkot, kominfo, DMI (dewan masjid Indonesia), Disparbudpora, Dinkes, TNI, Polda, Pol PP, NU, FKUB, Ansor dan pemadam.

Faktor yang menghambat keberhasilan pelaksanaan peraturan penerapan disiplin dan penegakan hukum protokol kesehatan antara lain yaitu: kurangannya kesadaran masyarakat terhadap bahaya covid-19 dan tidak begitu memperdulikan covid-19 sehingga terjadi gesekan antara petugas pelaksanaan peraturan dan masyarakat.

\section{SARAN}

Dari kesimpulan yang telah di uraikan diatas, selanjutnya penulis memberikan saran sebagai pertimbangan, sebagai berikut:

Berdasarkan hasil pembahasan dan kesimpulan penelitian yang telah dikemukakan maka peneliti memberikan saran sebagai berikut:

I. Disarankan kepada satuan tugas covid-19 kota Palangka Raya untuk terus memberikan sosialisasi terhadap masyarakat mengenai betapa berbahayanya covid-19 dan terus memberikan himbauan ketika berpatroli agar tetap mematuhi protokol kesehatan, melakukan pengawasan yang ketat terhadap tempattempat seperti pasar dan tempat-tempat tongkrongan anak muda.

2. Disarankan kepada satuan tugas covid-19 kota Palangka Raya untuk lebih mempertegas penindakan terhadap para pelaku usaha khususnya pelaku usaha yang membuka cafe atau tongkrongan anak muda yang melebihi jam buka yang telah diatur, karena ditempat tersebut banyak sekali pemuda yang berkumpul pada saat hari-hari atau malam-malam weekend, karena hasil dari wawancara didapatkan bahwa masih terdapat kerumunan ditempat tersebut. Maka dari itu cafe boleh buka namun mengurangi $50 \%$ dari kapasitas tempat sehingga ada jarak.

\section{METODOLOGI}

Metode kegiatan pengabdian terdiri dari 2 sub bab yaitu alat dan bahan serta metode pelaksanaan. Sub bab tersebut ditulis tanpa numbering maupun bullet. Cantumkan alatalat besar atau khusus yang digunakan dalam kegiatan pengabdian. Derajat dan spesifikasi untuk setiap bahan harus dicantumkan. Bagian ini jyga memuat jalannya pelaksanaan kegiatan pengabdian yang secara spesifik dilaksanakan. Alur kerja yang sederhana tidak perlu dibuat skema. Cara kerja yang sudah umum tidak perlu dijelaskan secara detail. Langkah pelaksanaan kegiatan yang panjang dapat dibuat dalam subbab tahapan-tahapan kegiatan dengan menggunakan numbering angka arab.

\section{DAFTAR PUSTAKA}

Anggito, Albi dan Setiawan, Johan. 2018. Metodologi Penelitian Kualitatif. Sukabumi : CV.Jejak

Arikunto, Suharsimi. 2010. Prosedur Penelitian:Suatu Pendekatan Praktik. Jakarta. PT Rineka Cipta 
Arikunto. Suharsimi. 1980. Dasar-Dasar Evaluasi Pendidikan. Jakarta. Bumi Aksara

Arliman.Laurensius. 2015. Komnas HAM dan Perlindungan Anak Pelaku Tindak Pidana. Yogyakarta. CV Budi Utama

Bungin, Burhan. 2012. Analisis Data Penelitian Kualitatif. Jakarta : Raja Grafindo Persada

Fakultas Ilmu Sosial dan Ilmu Politik. 2018. Panduan Penulisan Skripsi/Tesis. Palangka Raya : Universitas Muhammadiyah Palangka Raya

Gordon. Thomas. 1996. Mengajar Anak Berdisiplin Diri Dirumah dan Disekolah. Jakarta. PT Gramedia Pustaka Utama

Hutahaean. 2014. Sistem Informasi. Yogyakarta : Deepublish CV Budi Utama

Indriantoro, Nur., dan Supomo,. Bambang. 2013. Metodologi Penelitian Bisnis Untuk Akuntansi dan Manajemen. Yogyakarta : BPFE

James Brian Quinn. 2003. Strategy Process. New Jersey Prentice Hall

Lexy J. Moelong. 1990. Metodelogi Penelitian Kualitatif. Bandung : Remaja Rosdakarya

Muhammad. Sadi. 2017. Pengantar Ilmu Hukum. Jakarta. PT Kharisma Putra Utama

MUI.1983. Kependudukan. Kesehatan. Dan Pembangunan. Jakarta

Peratuaran Wali Kota Palangka Raya Nomor 26. 2020. Penerapan Disiplin Dan Penegakan Hukum Protokol Kesehatan. Palangka Raya

Rangkuti, F. 2013. Teknik membedakan kasus bisnis analisis SWOT cara penghitungan bobot, Rating, dan OCAI. Jakarta : PT. Gramedia Pustaka Utama

Salusu dan Raymond Young. 2015. Pengambilan Keputusan Stratejik Untuk Organisasi Publik Dan Organisasi Nonprofit. Jakarta : PT. Gramedia Widiasarana Indonesia

Sugiyono. 2017. Metode Penelitian. Kualitatif. Kuantitatif. Dan $R \& D$. Bandung. Alfabeta.CV.

Singodimedjo. M. 2002. Manajemen Sumber Daya Manusia. Surabaya. SMMAS

Undang-Undang No 23. 1992. Tentang Kesehatan. Jakarta. Presiden Republik Indonesia

Wali Kota Palangka Raya. 2021. SK 188.45 Satuan Tugas Penanganan dan Pencegahan Corona Virus Disease 2019 (covid-19). Palangka Raya

World Health Organization. 1997. Definisi Sehat WHO. Cited2016 20 Februari. Available From. WWW.who.int.

https://www.cnbcindonesia.com/tech/2020040609092937-149929/simak-penjelasan-who-soal-apaitu-corona-dan-cirinya

https://hellosehat.com/infeksi/infeksi-virus/coronavirusadalah/

https://dinkes.bantulkab.go.id/berita/800-mengenalcovid-19 